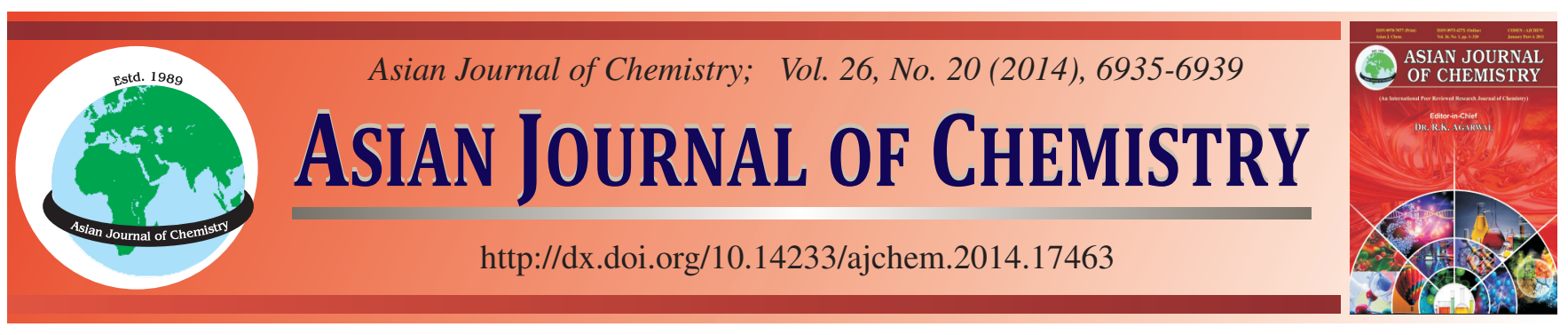

\title{
Relationship Among Chlorine Dose, Reaction Time and Bromide Ions on Trihalomethane Formation in Drinking Water Sources in Istanbul, Turkey
}

\author{
K. ÖZDEMIR ${ }^{1, *}$, I. TORÖZ² and V. UYAK ${ }^{3}$
}

${ }^{1}$ Bülent Ecevit University, Department of Environmental Engineering, Zonguldak, Turkey

${ }^{2}$ Istanbul Technical University, Department of Environmental Engineering, Istanbul, Turkey

${ }^{3}$ Department of Environmental Engineering, College of Engineering, Pamukkale University, Denizli, Turkey

*Corresponding author: Fax: +90 372 2574023; Tel: +90 372 2574010/1135; E-mail: kadirozdemir73@ yahoo.com

Received: 25 February 2014;

Accepted: 21 April 2014;

Published online: 25 September 2014;

AJC-16043

\begin{abstract}
We investigate the effects of factors such as chlorine dose, reaction time and bromide ions on the formation and speciation of trihalomethanes during the chlorination of Istanbul reservoirs such as Terkos lake water, Büyükçekmece lake water and Ömerli lake water. The experimental results showed that approximately $50 \%$ of trihalomethane formation was observed in the first $4 \mathrm{~h}$ of reaction time in chlorinated Terkos lake water, Büyükçekmece lake water and Ömerli lake water, respectively. Trihalomethane concentrations increased with increasing chlorine dosage and reaction time. Chloroform was the major trihalomethane species forming as a result of the chlorinated raw water samples. On the other hand, bromide ions play a great significant role in the distribution of trihalomethane species. The bromine and chlorine incorporation ratios were strongly related to natural organic matter precursors and bromide levels in Terkos lake water, Büyükçekmece lake water and Ömerli lake water. The percentage of bromine incorporation was much higher than that of chlorine in all chlorinated water samples.
\end{abstract}

Keywords: Drinking water, Trihalomethanes, Bromide, Chlorination.

\section{INTRODUCTION}

Chlorine is widely used as a disinfectant in water treatment technologies to eradicate pathogenic organisms and prevent the water-borne diseases ${ }^{1,2}$.

Nevertheless, water, including natural organic matter, reacts with chlorine and bromide ion and disinfection byproducts to form trihalomethanes (THMs) and halo acetic acids ${ }^{3-7}$. Many studies have reported that these unwanted byproducts also have adverse health effects on humans, such as retardation and congenital cardiac effects ${ }^{8-10}$. Due to the potential carcinogenicity of disinfection byproducts, many countries have established strict regulations to control disinfection byproducts ${ }^{11}$. For instance, the United States Environmental Projection Agency has set a maximum contamination level of $80 \mu \mathrm{g} / \mathrm{L}$ for trihalomethanes and $60 \mu \mathrm{g} / \mathrm{L}$ for five halo acetic acids; European Community regulates the levels of four brominated/ chlorinated trihalomethanes (chloroform, dichlorobromomethane, dibromochloromethane and bromoform, often called total trihalomethanes (TTHMs) at $100 \mu \mathrm{g} / \mathrm{L}^{12}$.

Furthermore, the trihalomethane limit in Turkey is 100 $\mu \mathrm{g} / \mathrm{L}$ (as total trihalomethanes) ${ }^{13}$. The formation and speciation of disinfection byproducts is known to be affected by chlorine dosage, reaction time, temperature, $\mathrm{pH}$, reactivity of natural organic matter and bromide concentration ${ }^{14-16}$. In particular, the chlorine dosage and the reaction time have a significant effect on the formation and distribution of disinfection byproduct species. Oliver and Lawrence ${ }^{17}$ reported that as the chlorine dose increased, trihalomethane formation also increased. This relationship has been observed in many studies $^{17-21}$. Furthermore, at low chlorine doses, substitution products dominate whereas oxidation and cleavage products dominate at higher chlorine doses 22 . The reaction kinetics of disinfection byproduct formation correspond to reaction time. When natural organic matter is chlorinated, the concentration of disinfection byproduct increases with increasing reaction time. Amy et $a l .^{23}$ studied trihalomethane formation during chlorination at reaction times ranging from 0.1 to $168 \mathrm{~h}$ and found that trihalomethanes form very fast in the first eight hours and slowly thereafter. In other words, the formation of trihalomethanes can be thought of as a two-stage process, with an initial rapid stage and a slower stage.

On the other hand, as a result of the chlorination of water containing high bromide $\left(\mathrm{Br}^{-}\right)$levels, brominated disinfection byproducts are generated ${ }^{24}$. This generation is explained by the oxidation of bromide to hypobromous acid $(\mathrm{HOBr})$, which reacts by hypochlorous $(\mathrm{HOCl})\left(\mathrm{Br}^{-}+\mathrm{HOCl} \rightarrow \mathrm{HOBr}+\mathrm{Cl}^{-}\right)^{25,26}$. 
Free chlorine generated in the analog forms of $\mathrm{HOCl}$ and hypochlorite $\left(\mathrm{OCl}^{-}\right)$is related to $\mathrm{pH}$ levels. $\mathrm{HOBr}$ reacts with natural organic matter faster than $\mathrm{HOCl}$. Moreover, chlorine can preferentially acts as an oxidant, whereas bromine can acts as a substituting agent ${ }^{27-29}$. Nonetheless, the different ratios of $\mathrm{HOBr} / \mathrm{HOCl}$ affect the distribution of brominated and chlorinated disinfection byproducts ${ }^{30,31}$. Here, the bromine incorporation factor was employed as a useful parameter to determine the distribution of trihalomethane compounds during the chlorination of water samples, including natural organic matter ${ }^{32,33}$. Many previous studies have examined bromine incorporation factors and the effects of bromide on disinfection byproduct formation during chlorination ${ }^{32-35}$. These studies have shown that disinfection byproducts such as trihalomethane speciation and bromine formation are closely related to bromide concentration.

The goal of this study is to investigate the effects of factors such as chlorine dosage, reaction time and bromide ions on the formation and speciation of trihalomethanes. For this study, water samples were collected from three drinking water reservoirs of Istanbul in Turkey: Terkos lake water, Büyükçekmece lake water and Ömerli lake water. These three raw water samples were chlorinated in different experimental conditions to predict the concentration of trihalomethane species.

\section{EXPERIMENTAL}

Sample collection: During this study, water samples were taken from Terkos lake water, Büyükçekmece lake water and Ömerli lake water in Istanbul, Turkey. Samples were collected during the fall period (September, October and November) in 2009. Approximately 2.5 million $\mathrm{m}^{3}$ of drinking water per day is provided by these reservoirs in Istanbul. Raw water samples were collected by plant personnel as a grab sample and shipped to a water quality laboratory (Istanbul Water Utilities Administration (ISKI)) on the same day. The characteristics of the raw water quality parameters are presented in Table- 1 . The water samples were kept in the dark in a refrigerator at $4{ }^{\circ} \mathrm{C}$ to prevent biological activity prior to use.

\begin{tabular}{|c|c|c|c|c|}
\hline \multicolumn{5}{|c|}{$\begin{array}{l}\text { TABLE-1 } \\
\text { PHYSICO-CHEMICAL CHARACTERISTICS } \\
\text { OF THE TLW, BLW AND OLW SAMPLES }\end{array}$} \\
\hline Parameter & Unit & TLW & BLW & OLW \\
\hline & & $\begin{array}{c}\text { Average } \\
\text { value }\end{array}$ & $\begin{array}{c}\text { Average } \\
\text { value }\end{array}$ & $\begin{array}{c}\text { Average } \\
\text { value }\end{array}$ \\
\hline $\mathrm{pH}$ & - & $7.97 \pm 0.16$ & $8.19 \pm 0.14$ & $7.32 \pm 0.21$ \\
\hline Turbidity & NTU & $3.34 \pm 0.46$ & $3.24 \pm 0.27$ & $3.14 \pm 0.34$ \\
\hline $\begin{array}{l}\text { Total } \\
\text { hardness }\end{array}$ & $\mathrm{mg} \mathrm{CaCO} / \mathrm{L}$ & $116.3 \pm 6.7$ & $166.4 \pm 10.3$ & $76.3 \pm 5.3$ \\
\hline Alkalinity & $\mathrm{mg} \mathrm{CaCO} / \mathrm{L}$ & $103.1 \pm 7.53$ & $114.6 \pm 7.7$ & $67.1 \pm 5.1$ \\
\hline Temperature & ${ }^{\circ} \mathrm{C}$ & $17.2 \pm 2.3$ & $17.1 \pm 2.1$ & $16.2 \pm 2.03$ \\
\hline TOC & $\mathrm{mg} / \mathrm{L}$ & $4.78 \pm 0.3$ & $4.71 \pm 0.45$ & $4.47 \pm 0.29$ \\
\hline $\mathrm{UV}_{254}$ & $\mathrm{~cm}^{-1}$ & $0.13 \pm 0.01$ & $0.095 \pm 0.008$ & $0.086 \pm 0.00$ \\
\hline $\mathrm{Br}$ & $\mu \mathrm{g} / \mathrm{L}$ & $120 \pm 20$ & $200 \pm 20$ & $70 \pm 10$ \\
\hline THMFP & $\mu \mathrm{g} / \mathrm{L}$ & $278 \pm 30.2$ & $230 \pm 24.4$ & $214 \pm 21$ \\
\hline Conductivity & $\mu \mathrm{S} / \mathrm{cm}$ & $305 \pm 13.5$ & $470 \pm 16$ & $215.3 \pm 11$ \\
\hline SUVA & $\mathrm{L} / \mathrm{mg} \mathrm{m}$ & $2.53 \pm 0.14$ & $2.02 \pm 0.23$ & $1.93 \pm 0.12$ \\
\hline
\end{tabular}

TLW: Terkos lake water; BLW: Büyükçekmece lake water; OLW: Ömerli lake water; TOC: Total organic carbon; THMFP: trihalomethane formation potential
Chlorination procedure: Chlorination of the raw water samples was conducted in accordance with standard methods $5710 \mathrm{~B}^{36}$. Before chlorination, the $\mathrm{pH}$ values of samples were buffered to a $\mathrm{pH}$ of 7 using a phosphate buffer (adjusted with $\mathrm{HCl}$ and $\mathrm{NaOH}$ solution, if necessary). A chlorine stock solution was prepared from $5 \%$ sodium hypochlorite and the concentration $(5 \mathrm{mg} / \mathrm{mL})$ was obtained calorimetrically by the method $4500-\mathrm{Cl}-\mathrm{G}$ in the standard methods ${ }^{36}$. The chlorinated samples were placed in $125 \mathrm{~mL}$ amber glass bottles with Teflonfaced silicone septum screw caps. After that, the samples were incubated in a dark room for the given reaction times.

Analytical procedure: Liquid-liquid extraction with $n$-pentane was used for total trihalomethane measurements. For trihalomethanes, a total of six trihalomethane calibration standards were prepared using certificated commercial mix solutions (Accu Standard, Inc., USA, purity > $99 \%$ ). Samples were analyzed by gas chromatography equipped with a micro electron capture detector $(\mu \mathrm{ECD})$ for trihalomethane analyses. Total organic carbon (TOC) concentrations were measured on a Shimadzu 5000 total carbon analyzer equipped with an auto sampler according to method $5310 \mathrm{~B}$ in the standard methods $\mathrm{s}^{36}$. The ultraviolet (UV) absorbance readings at $254 \mathrm{~nm}$ were determined with a Shimadzu 1608 UV/visual spectrophotometer. The concentration of bromide ions was measured via ion chromatogram (ICS-3000; Dionex, USA).

\section{RESULTS AND DISCUSSION}

Reaction kinetics of trihalomethane formation: A typical kinetic profile of total trihalomethane production, including reaction times from $2-168 \mathrm{~h}$, dosed with $10 \mathrm{mg} / \mathrm{L}$ of chlorine at a $\mathrm{pH}$ of 7 in raw water samples from the three main reservoirs (Fig. 1).

The formation of trihalomethanes commonly proceeded in two stages according to Fig. 1: An initial stage was completed rapidly within the first few hours and a slower, later, stage was marked by a steady rate of increase. Approximately $50 \%$ of trihalomethanes were produced within the first $4 \mathrm{~h}$ and $90 \%$ of trihalomethane formation corresponds to a $96 \mathrm{~h}$ reaction time, in comparison with a final $168 \mathrm{~h}$ trihalomethane formation potential. Nonetheless, Krasner et al. ${ }^{37}$ also reported that about $70-90 \%$ of the trihalomethanes formed within the first $24 \mathrm{~h}$, as compared with $172 \mathrm{~h}$ for the trihalomethane formation potential (THMFP). Additionally, the dosage of applied chlorine has a significant effect on the formation of trihalomethanes. In general, increasing the chlorine concentration increases the formation of trihalomethanes. The formation of trihalomethanes in chlorinated raw water from Terkos lake water, Büyükçekmece lake water and Ömerli lake water samples as a function of different applied chlorine dosages and reaction times is shown in Table- 2 .

As seen in Table-2, when a chlorine dosage of $10 \mathrm{mg} / \mathrm{L}$ was injected into the Terkos lake water, Büyükçekmece lake water and Ömerli lake water samples, the amounts of total trihalomethanes formed were determined to be 257.91, 209.87 and $193.88 \mu \mathrm{g} / \mathrm{L}$, respectively, for a reaction time of $168 \mathrm{~h}$. On the contrary, for a chlorine dosage of $5 \mathrm{mg} / \mathrm{L}$, the amounts of total trihalomethane formed were measured to be $163.13,137.55$ and $110.15 \mu \mathrm{g} / \mathrm{L}$ for the Terkos lake water, Büyükçekmece lake water and Ömerli lake water samples, respectively, under the 
TABLE-2

FORMATION OF TTHMS IN CHLORINATED TLW, BLW AND OLW SAMPLES FOR VARYING REACTION TIMES AND CHLORINE DOSAGES

\begin{tabular}{ccccccc}
\hline & \multicolumn{2}{c}{ TLW } & \multicolumn{2}{c}{ BLW } & \multicolumn{2}{c}{ OLW } \\
\cline { 2 - 7 } \begin{tabular}{c} 
Reaction $\begin{array}{c}\text { time } \\
\text { (hours) }\end{array}$ \\
\cline { 2 - 7 }
\end{tabular} & $\begin{array}{c}\text { TTHM } \\
(\mu \mathrm{g} / \mathrm{L})\end{array}$ & $\begin{array}{c}\text { TTHM } \\
(\mu \mathrm{g} / \mathrm{L})\end{array}$ & $\begin{array}{c}\text { TTHM } \\
(\mu \mathrm{g} / \mathrm{L})\end{array}$ & $\begin{array}{c}\text { TTHM } \\
(\mu \mathrm{g} / \mathrm{L})\end{array}$ & $\begin{array}{c}\text { TTHM } \\
(\mu \mathrm{g} / \mathrm{L})\end{array}$ & $\begin{array}{c}\text { TTHM } \\
(\mu \mathrm{g} / \mathrm{L}\end{array}$ \\
\hline 2 & $\begin{array}{c}\mathrm{Cl}_{2}=10 \\
\mathrm{mg} / \mathrm{L})\end{array}$ & $\begin{array}{c}\mathrm{Cl}_{2}=5 \\
(\mathrm{mg} / \mathrm{L})\end{array}$ & $\begin{array}{c}\mathrm{Cl}_{2}=10 \\
(\mathrm{mg} / \mathrm{L})\end{array}$ & $\begin{array}{c}\mathrm{Cl}_{2}=5 \\
(\mathrm{mg} / \mathrm{L})\end{array}$ & $\begin{array}{c}\mathrm{Cl}_{2}=10 \\
(\mathrm{mg} / \mathrm{L})\end{array}$ & $\begin{array}{c}\mathrm{Cl}_{2}=5 \\
(\mathrm{mg} / \mathrm{L})\end{array}$ \\
\hline 4 & 129.11 & 63.03 & 77.39 & 48.88 & 70.45 & 41.36 \\
12 & 148.64 & 102.21 & 98.92 & 80.52 & 85.96 & 69.21 \\
24 & 179.51 & 116.73 & 115.24 & 94.34 & 96.11 & 83.47 \\
48 & 196.22 & 125.23 & 156.77 & 113.42 & 133.51 & 101.62 \\
72 & 210.46 & 136.69 & 167.03 & 121.2 & 142.98 & 109.88 \\
96 & 229.02 & 150.26 & 185.41 & 128.09 & 159.89 & 116.44 \\
168 & 257.91 & 163.13 & 209.87 & 137.55 & 186.27 & 126.12 \\
\hline
\end{tabular}

TLW: Terkos lake water; BLW: Büyükçekmece lake water; OLW: Ömerli lake water; TOC: Total organic carbon; TTHMs: trihalomethanes
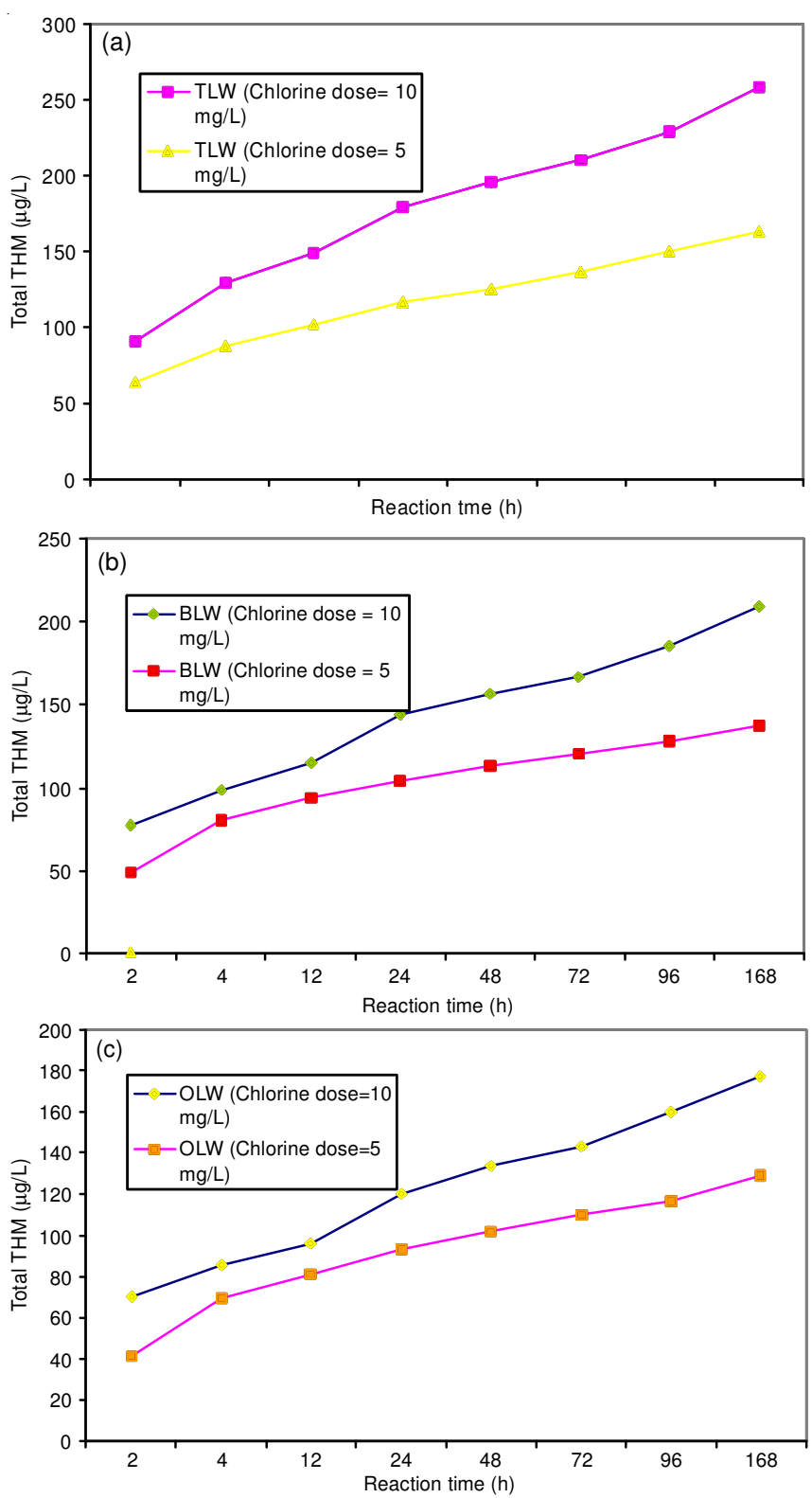

Fig. 1. Formation of total trihalomethanes as a function of reaction time and chlorine dosage at $\mathrm{pH}=7$ for (a) chlorinated terkos lake water samples, (b) chlorinated büyükçekmece lake water samples and (c) chlorinated Ömerli lake water samples same conditions. This result implies that the trihalomethane concentrations increase with increasing chlorine dosage.

Distribution of trihalomethane species: The formation and distribution of trihalomethane species in chlorinated water of the Terkos lake water, Büyükçekmece lake water and Ömerli lake water samples is shown in Fig. 2.
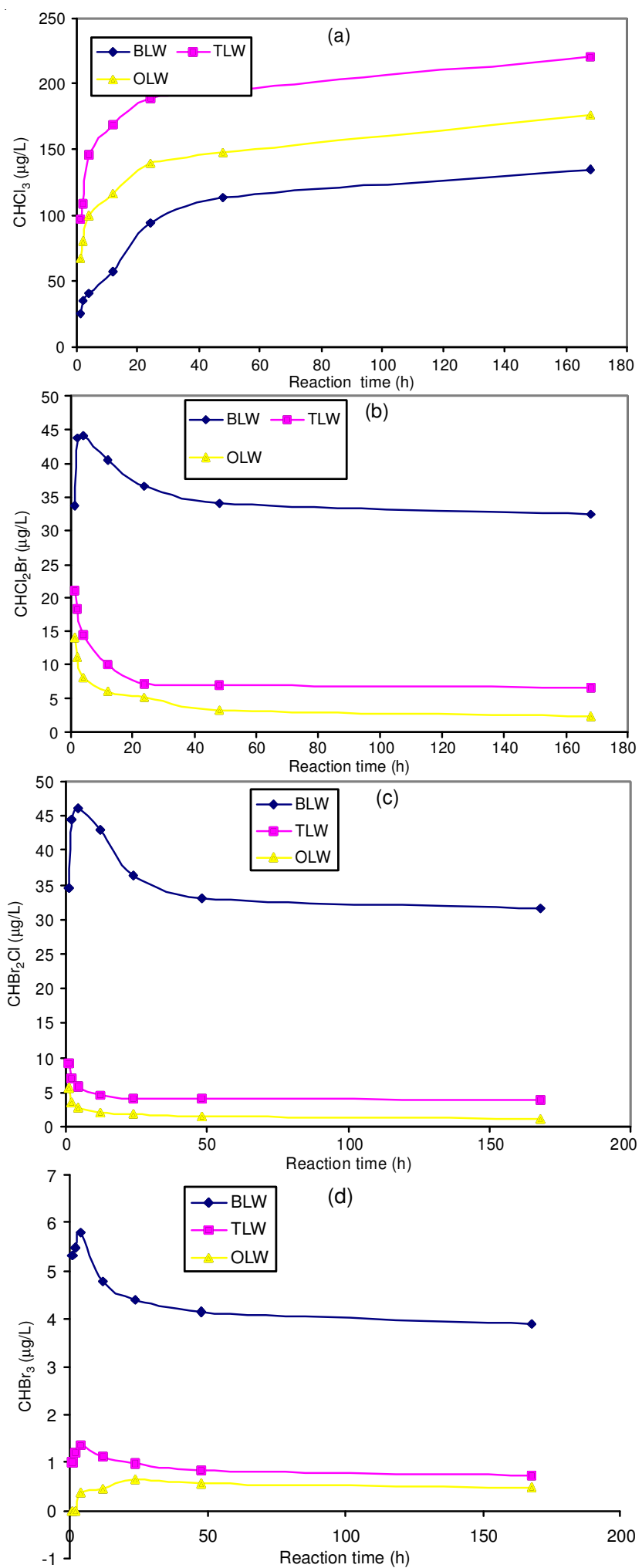

Fig. 2. Formation and distribution of trihalomethane species in the chlorinated water of the Terkos lake water, Büyükçekmece lake water and Ömerli lake water samples for (a) $\mathrm{CHCl}_{3}$, (b) $\mathrm{CHCl}_{2} \mathrm{Br}$, (c) $\mathrm{CHClBr}_{2}$ and (d) $\mathrm{CHBr}_{3}$ 
At the beginning of the reaction of trihalomethane formation, the concentrations of brominated species increased quickly. Since the bromine was used up after a reaction time of $12 \mathrm{~h}$, the level of brominated species decreased while the level of $\mathrm{CHCl}_{3}$ continued to increase. As shown in Figs. 2-4, $\mathrm{CHCl}_{3}$ was the dominant species among the four trihalomethane compounds. The maximum concentration of $\mathrm{CHCl}_{3}$ in chlorinated raw water samples during the reaction of $168 \mathrm{~h}$ was observed in Terkos lake water samples to be $220.42 \mu \mathrm{g} / \mathrm{L}$. On the other hand, due to the moderate level of bromide ions (200 $\mu \mathrm{g}$ in Büyükçekmece lake water, the concentrations of $\mathrm{CHClBr}_{2}$ and $\mathrm{CHCl}_{2} \mathrm{Br}$ were higher than that of $\mathrm{CHCl}_{3}$ within the reaction time of $12 \mathrm{~h}$. During the reaction time of $12 \mathrm{~h}$, $44.12 \mu \mathrm{g} / \mathrm{L}$ of $\mathrm{CHCl}_{2} \mathrm{Br}$ and $46.06 \mu \mathrm{g} / \mathrm{L}$ of $\mathrm{CHClBr}_{2}$ were formed (Fig. 2). These results have also shown that the chlorination of high levels of bromide-containing water modifies the chlorination process, i.e., bromide is rapidly oxidized to bromine and directly affects the formation and distribution of trihalomethane species. Besides, as compared with specific ultraviolet absorbance (SUVA) levels of terkos lake water (specific ultraviolet absorbance $=2.53 \mathrm{~L} / \mathrm{mg} \mathrm{m}$ ), Büyükçekmece lake water (specific ultraviolet absorbance $=2.02 \mathrm{~L} / \mathrm{mg}$ m) and Ömerli lake water (specific ultraviolet absorbance = $1.93 \mathrm{~L} / \mathrm{mg} \mathrm{m}$ ), bromine is more reactive with the hydrophilic fraction of natural organic matter for each raw water sample in the formation of trihalomethanes (Table-1). As shown in Fig. 2, $\mathrm{CHBr}_{3}$ has the lowest concentration within the other trihalomethane species in all water samples. Although the maximum $\mathrm{CHBr}_{3}$ concentration was measured to be $5.99 \mu \mathrm{g} / \mathrm{L}$ in chlorinated büyükçekmece lake water within the reaction time of $2 \mathrm{~h}$, Terkos lake water and Ömerli lake water showed concentrations ranging from 1.36 to $0.45 \mu \mathrm{g} / \mathrm{L}$. This result corresponds to the lower bromide level in the terkos lake water and Ömerli lake water samples compared with the büyükçekmece lake water sample. Also, these results are confirmed by several studies ${ }^{26,29,38,39}$.

Bromine and chlorine incorporation: To evaluate bromine and chlorine substitutions during trihalomethane formation in this study, the ratio of bromine and chlorine incorporation was used. The percentage of bromide incorporated into trihalomethanes was calculated as follows:

Percent of bromine incorporation $(\%)=[(\mathrm{THM}-\mathrm{Br}$ $\left.\left.(\mu \mathrm{mol})) / \mathrm{Br}^{-}(\mu \mathrm{mol})\right)\right] \times 100$, where $\mathrm{THM}-\mathrm{Br}(\mu \mathrm{g} / \mathrm{L})=79.9$ $\left[\mathrm{CHCl}_{2} \mathrm{Br}\right] / 163.8+2\left[\mathrm{CHClBr}_{2}\right] / 208.25+3\left[\mathrm{CHBr}_{3}\right] / 252.7$.

Percent of chlorine incorporation $(\%)=[($ THM $-\mathrm{Cl}$ $\left.\left.(\mu \mathrm{mol})) / \mathrm{Cl}^{-}(\mu \mathrm{mol})\right)\right] \times 100$, where THM-Cl $(\mu \mathrm{g} / \mathrm{L})=35.5$ $\left[\mathrm{CHCl}_{3}\right] / 119.5+\left[\mathrm{CHClBr}_{2}\right] / 208.25+2\left[\mathrm{CHCl}_{2} \mathrm{Br}\right] / 163.8$.

The percentages of bromine and chlorine incorporated are shown in Fig. 3.

As shown in Fig. 3, the percentages of bromine incorporation were higher than those of chlorine in chlorinated water samples.

The highest bromination rate was observed in the first $4 \mathrm{~h}$ of reaction time in all chlorinated water samples. At the same time, the highest bromine incorporation ratio was found in chlorinated Büyükçekmece lake water (68\%), at a reaction time of $4 \mathrm{~h}$. On the other hand, the bromine incorporation ratios in chlorinated Terkos lake water and Ömerli lake water
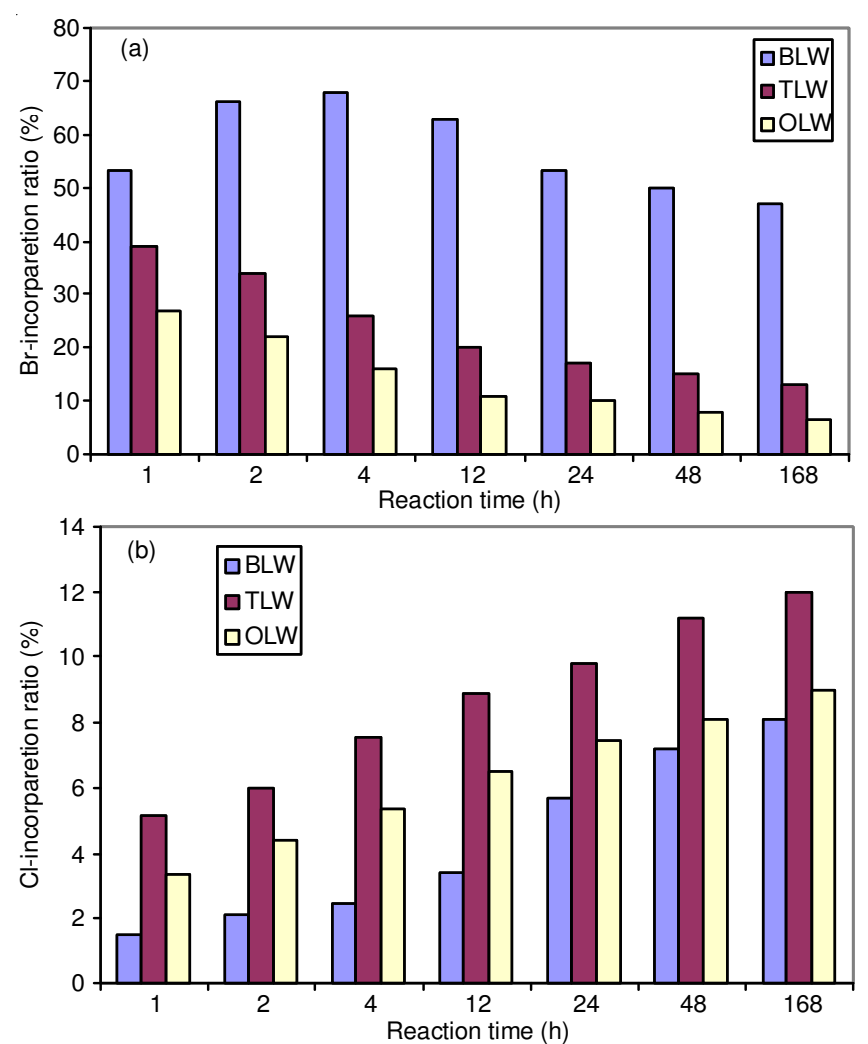

Fig. 3. (a) Percentages of bromine incorporation in chlorinated büyükçekmece lake water, terkos lake water and Ömerli lake water samples (b) percentages of chlorine incorporation in chlorinated büyükçekmece lake water, terkos lake water and Ömerli lake water samples

decreased steadily with reaction time, whereas chlorine in corporation ratio increased (Fig. 3). These observations affirm that bromine is more reactive than chlorine in the substitution and addition reactions that form trihalomethanes. The low chlorine utilization (1.5-12\%) apparently suggests that much of the chlorine was converted to chloride ions via oxidation reactions. Another important result of this experimental study shows that bromine utilization is strongly dependent on the nature of the natural organic matter precursors. In other words, more bromine and less chlorine were incorporated into trihalomethanes by the hydrophilic fraction, because bromine is more reactive with aliphatic precursors than with aromatic precursors. This finding is consistent with the results obtained by Huang and $\mathrm{Yeh}^{40}$ and Hua and Reckhow ${ }^{29,41}$. Moreover, this result verifies the hypothesis proposed by Heller-Grossman and coworkers ${ }^{29,42}$. Fig. 4 summarizes the reaction pathway for trihalomethane formation in chlorinated Büyükçekmece lake water, Terkos lake water and Ömerli lake water samples.

As shown in Fig. 4, $\mathrm{k}_{1}>\mathrm{k}_{2}$ demonstrates a preference for bromination of aliphatic precursors in chlorinated Terkos lake water, Büyükçekmece lake water and Ömerli lake water, samples. Therefore, it is concluded that aliphatic structures play a significant role in trihalomethane formation in chlorinated Istanbul drinking water sources.

The concentration of trihalomethanes formed when natural organic matter is chlorinated increases with time. Approximately $50 \%$ of trihalomethanes were produced within the first $4 \mathrm{~h}$ of reaction time. In general, trihalomethane concen- 


\begin{tabular}{|c|c|c|c|}
\hline $\mathrm{H}$ & & $\begin{array}{l}\text { Aliphatic precursors } \\
\mathrm{R}=\mathrm{C}-\mathrm{CH}_{2}-\mathrm{C}-\mathrm{R}\end{array}$ & $\mathrm{k}_{1}$ \\
\hline O & + & Aromatic precursor & $\mathrm{k}_{2}$ \\
\hline
\end{tabular}

Fig. 4. Pathways to trihalomethane formation in chlorinated Terkos lake water, Büyükçekmece lake water and Ömerli lake water samples

trations increase with increasing chlorine dose. When a chlorine dosage of $10 \mathrm{mg} / \mathrm{L}$ was injected into the Terkos lake water, Büyükçekmece lake water and Ömerli lake water samples, the amounts of trihalomethanes formed were 257.91, 209.87 and $193.88 \mu \mathrm{g} / \mathrm{L}$, respectively, for a reaction time of $168 \mathrm{~h}$. On the contrary, for a chlorine dosage of $5 \mathrm{mg} / \mathrm{L}$, the amounts of trihalomethanes formed were 163.13, 137.55 and $110.15 \mu \mathrm{g} / \mathrm{L}$ for the Terkos lake water, Büyükçekmece lake water and Ömerli lake water samples, respectively.

Among all trihalomethane species, $\mathrm{CHCl}_{3}$ was the main trihalomethane species that formed as a result of the chlorinated Terkos lake water, Büyükçekmece lake water and Ömerli lake water samples. The formations of trihalomethane species were consistent with increasing bromide levels. In this study, due to the moderate level of bromide ions in the Büyükçekmece lake water sample, the formation of $\mathrm{CHClBr}_{2}$ and $\mathrm{CHCl}_{2} \mathrm{Br}$ was increased relative to that of $\mathrm{CHCl}_{3}$ in the first $4 \mathrm{~h}$ of reaction time.

The bromine incorporation ratio was strongly dependent on the nature of the natural organic matter precursors and was related to the specific ultraviolet absorbance levels of Terkos lake water, Büyükçekmece lake water and Ömerli lake water. Since the Istanbul reservoirs have low specific ultraviolet absorbance levels (2-2.5 L/mg m), more bromine and less chlorine were incorporated into trihalomethanes by the hydrophilic fraction. Therefore, the hydrophilic fraction of natural organic matter plays a relatively more important role in trihalomethane formation for chlorinated Terkos lake water, Büyükçekmece lake water and Ömerli lake water samples.

\section{REFERENCES}

1. W.E. Elshorbagy, H. Abu-Qadais and M.K. Elsheamy, Water Res., 34, 3431 (2000).

2. S.K. Golfinopoulos and G.B. Arhonditsis, Chemosphere, 47, 107 (2000).

3. M. Palacios, J.F. Pampillon and M.E. Rodriguez, Water Res., 34, 1002 (2000)

4. R. Sadiq and M.J. Rodriguez, Sci. Total Environ., 321, 21 (2004).

5. G. Hua and D.A. Reckhow, Water Res., 46, 4208 (2012).

6. R.J. Bull, L.S. Birnbaum, K.P. Cantor, J.B. Rose, B.E. Butterworth, R. Pegram and J. Tuomisto, Appl. Toxicol., 28, 155 (1995).
7. V. Uyak, I. Toroz and S. Meric, Desalination, 176, 91 (2005).

8. M.I. Cedergren, A.J. Selbing, O. Löfman and A.J. Bengt, Environ. Res., 89, 124 (2002).

9. I. Ivancev-Tumbas, B. Dalmacija, Z. Tamas and E. Karlovic, Water Res., 33, 3715 (2002).

10. C.Y. Yang, B.H. Cheng, S.S. Tsai, T.N. Wu, M.C. Lin and K.C. Lin, Environ. Health Perspect., 108, 765 (2000).

11. WHO, Environmental Health Criteria 216: Disinfectants and Disinfectant By-products, World Health Organization, Geneva (2000).

12. S.D. Richardson, M.J. Plewa, E.D. Wagner, R. Schoeny and D.M. Demarini, Mutat. Res., 636, 178 (2007).

13. TMH, Regulation Concerning Water Intended for Human Consumption, Turkish Ministry of Health, Official News Paper, No: 25730, Ankara, (2012).

14. A. Adin, J. Katzhendler, D. Alkaslassy and C. Rav-Acha, Water Res., 25, 797 (1991).

15. G.A. Cowman and P.C. Singer, Environ. Sci. Technol., 30, 16 (1996).

16. J.P. Croue G.V. Korshin and M.M. Benjamin, Characterization of Natural Organic Matter in Drinking Water, American Water Works Association Research Foundation, Denver, CO (2000).

17. B.G. Oliver and J. Lawrance, J. Am. Water Works Assoc., 71, 161 (1979).

18. S.J. Fleischacker and S.J. Randtke, J. Am. Water Works Assoc., 50, 132 (1983).

19. D.L. Norwood, J.D. Johnson, R.F. Christman, J.R. Hass and M.J. Bobenrieth, Environ. Sci. Technol., 14, 187 (1980).

20. J.J. Rook, Water Treat. Exam., 2, 234 (1974).

21. D.A. Reckhow and P.C. Singer, Environ., Impact Health Effects, 5, 1229 (1985).

22. J.D. Johnson and J.N. Jensen, J. Am. Water Works Assoc., 78, 156 (1986).

23. G.L. Amy, P.A. Chadik and Z. Chowdhury, J. Am. Water Works Assoc., 79, 89 (1987).

24. I. Toroz and V. Uyak, Desalination, 176, 127 (2005).

25. J.C. Morris, in ed.: R.L. Jolley, The Chemistry of Aqueous Chlorine in Relation to Water Chlorination, Ann Arbor Science, Ann Arbor, MI (1978).

26. A. Kampioti, Water Res., 36, 2596 (2002).

27. J.M. Symons, S.W. Krasner, L.A. Simms and M.J. Sclimenti, J. Am. Water Works Assoc., 85, 51 (1993).

28. T.V. Luong, C.J. Peters and R. Perry, Environ. Sci. Technol., 16, 473 (1982).

29. S. Hu, F. Yang, S. Liu and L. Yu, Water Res., 43, 381 (2009).

30. V. Uyak and I. Toroz, J. Hazard. Mater., 149, 445 (2007).

31. G.A. Cowman and P.C. Singer, Environ. Sci. Technol., 30, 16 (1996).

32. J. Sohn, G. Amy and Y. Yoon, Water Air Soil Pollut., 174, 265 (2006).

33. R.E. Rathbun, Sci. Total Environ., 192, 111 (1996).

34. I.N. Najm and S.W. Krasner, J. Am. Water Works Assoc., 87, 106 (1995).

35. T.D. Lekkas and A.D. Nikolaou, Water Qual. Res. J. Canada, 39, 149 (2004).

36. APHA, AWWA, WEF, Standard Methods for the Examination of Water and Wastewater, Washington, DC, edn 21 (2005).

37. S.W. Krasner, M.J. McGuire, N.L. Jacangelo, K.M. Patania and E.M. Aieta, J. Am. Water Works Assoc., 81, 41 (1989).

38. X. Yang, C. Shang and J.C. Huang, Water Res., 39, 4755 (2005).

39. X. Yang and C. Shang, Environ. Sci. Technol., 38, 4995 (2004).

40. J.W. Huang and H.H. Yeh, J. Environ. Sci. Health A, 32, 2311 (1997).

41. G.H. Hua and D.A. Reckhow, Environ. Sci. Technol., 41, 3309 (2007).

42. L. Heller-Grossman, J. Manka, B. Limoni-Relis and M. Rebhun, Water Res., 27, 1323 (1993). 